\title{
Is inflammation a new risk factor of depression in haemodialysis patients?
}

\author{
Lukasz Nowak · Marcin Adamczak • Andrzej Więcek
}

Received: 7 May 2012/Accepted: 8 August 2012/Published online: 13 September 2012

(C) The Author(s) 2012. This article is published with open access at Springerlink.com

\begin{abstract}
Purpose Prevalence of depression is high in patients with chronic kidney disease. Depression is associated with increased mortality and the higher rate of suicides in these patients. The aim of the study was to estimate the prevalence of depressive symptoms in haemodialyzed patients in Upper Silesia region of Poland and the possible role of inflammation in depression development.

Methods Six hundred and ninety-seven haemodialyzed patients from 22 dialysis centres in Upper Silesia region of Poland were enrolled into the study. Mean age was $59.1 \pm 0.5$ years, and mean time of dialysis treatment was $3.6 \pm 0.2$ years. Each patient received 21-item Beck Depression Inventory (BDI) questionnaire for depression screening. Additional questions considering length of dialysis treatment, concomitant diseases and number of days spent in hospitals during the last year were also asked.

Results Depressive symptoms were found in 268 (38.6\%) patients. Patients with depressive symptoms when compared with the patients without them tended to have higher C-reactive protein plasma concentration
\end{abstract}

Ł. Nowak $(\bowtie) \cdot$ M. Adamczak · A. Więcek

Department of Nephrology, Endocrinology and Metabolic

Disorders, Medical University of Silesia,

Francuska 20-24, 40-027 Katowice, Poland

e-mail: lukas130673@wp.pl

A. Więcek

e-mail: awiecek@spskm.katowice.pl
$(14.3 \pm 1.3$ vs. $11.1 \pm 0.9 \mathrm{mg} / \mathrm{l} ; p=0.067)$ and were more often dialyzed with central catheter (27.6 vs. $18.2 \% ; p=0.0042)$. During the last year, patients with depressive symptoms spent in hospitals more days than patients without depressive symptoms ( 24.3 vs. 15.3 days, respectively; $p<0.0001)$. Significant positive correlation between BDI score and C-reactive protein level $(r=0.1625 ; p=0.001)$ was found both in univariate and multivariate analysis.

Conclusions (1) Depressive symptoms are frequently found $(38.6 \%)$ in haemodialyzed patients in Upper Silesia part of Poland. (2) Catheter placement and inflammation seem to play an important role in the pathogenesis of depression in haemodialysis patients.

Keywords Chronic kidney disease - Haemodialysis · Depression · Inflammation

\section{Introduction}

Depression issue in haemodialyzed patients has been addressed many times in the past, and by now, we may expect about 3,000 haemodialyzed patients diagnosed for depression described in the literature through the last 30 years. During this time, a rapid and pronounce development in renal replacement therapy was observed which was followed by deep change in profile of haemodialyzed population. However, depression rate in chronic kidney disease (CKD) patients does not differ from general population [1], 
and reported prevalence of depression in ESRD patients is much higher than in general population [2], did not change over time [3-9] and is the most common psychiatric disorder in this group of patients [10]. The diagnosis of depression still remains challenging which was shown by Donna Grant in 2008 on British population of haemodialyzed patients [11].

Depression negatively influences compliance with medical treatment and dietary adherence in different groups of chronically ill patients, including patients with CKD and ESRD [12-14]. That in turn can be associated with poor outcomes in CKD patients independently of other clinical factors like CKD stage, serum albumin, haemoglobin blood or phosphorus plasma concentrations and comorbidities [15, 16]. It was proven that depression influences the lifetime of patients with CKD [17-19] and may affect suicide rate in this population [20].

Etiopathology of depression in patients with CKD is multifactorial, both medically and psychologically based. Theory of major loses explains both backgrounds for depression development. Sense of loss accompanies patients from very early stages of CKD to the most profound loss in ESRD. Additional factors also influence development of depression in ESRD patients. Chronic pain and sleep disturbances affect health-related quality of life (HRQOL) and depression in patients with all stages of CKD [21] and with ESRD [22-24], with regard to not clear causality and order. Additionally, numerous authors underline role of patient's inflammatory status in depression development [25-28].

Since there is little data about prevalence of depression in haemodialyzed population in Poland, we designed a study on large group of haemodialyzed patients to address this issue. We also wanted to identify potential risk factors for depression development in this population with regard to inflammatory status. The question arises: is depression a new player in MIA syndrome? Confirming this hypothesis may result in changing MIA to MIAD syndrome abbreviation (malnutrition-inflammation-atherosclerosis-depression) in the future.

\section{Materials and methods}

Six hundred and ninety-four haemodialyzed patients from 22 dialysis centres in Upper Silesia region of
Poland were enrolled into the study. Patients' characteristics were shown in Tables 1 and 2. Each patient received questionnaire consisting of the parts: Beck Depression Inventory (BDI) test, social data and medical history data.

Presence of depressive symptoms was measured with BDI [29] that is a well-validated measure of depression in patients with ESRD [4]. The BDI is a 21-item, patient self-rated scale that has been used in

Table 1 Characteristics - clinical data of dialyzed patients with chronic kidney disease

\begin{tabular}{|c|c|}
\hline Number of patients & 694 \\
\hline \multicolumn{2}{|l|}{ Gender } \\
\hline Male & $387(55.7 \%)$ \\
\hline Female & $307(44.3 \%)$ \\
\hline Age (years) & $59.1 \pm 0.5$ \\
\hline Weight (kg) & $71.2 \pm 0.6$ \\
\hline Height (cm) & $166.5 \pm 0.4$ \\
\hline Haemodialysis time per week (h) & $12.5 \pm 0.2$ \\
\hline Haemodialysis time (years) & $3.6 \pm 0.2$ \\
\hline \multicolumn{2}{|l|}{ Vascular access } \\
\hline Venous catheter & $159(24.2 \%)$ \\
\hline Arterio-venous fistula & $535(75.8 \%)$ \\
\hline \multicolumn{2}{|l|}{ Dialysis centre } \\
\hline Non-profit & $434(63.4 \%)$ \\
\hline Commercial & $260(36.6 \%)$ \\
\hline \multicolumn{2}{|l|}{ Cause of $\mathrm{CKD}^{\mathrm{a}}$} \\
\hline Diabetes mellitus & $148(21.2 \%)$ \\
\hline Hypertension & $284(40.7 \%)$ \\
\hline Glomerulonephritis & $122(17.5 \%)$ \\
\hline Other & $96(13.8 \%)$ \\
\hline \multicolumn{2}{|l|}{ Other diseases $^{\mathrm{a}}$} \\
\hline Chronic pulmonary obstructive disease & $17(2.4 \%)$ \\
\hline Coronary artery disease & $166(23.8 \%)$ \\
\hline History of myocardial infarction & $83(11.9 \%)$ \\
\hline History of stroke & $43(6.2 \%)$ \\
\hline Glaucoma & $45(6.5 \%)$ \\
\hline Hearing problems & $109(15.6 \%)$ \\
\hline \multicolumn{2}{|l|}{ Laboratory results } \\
\hline Haemoglobin (g/dl) & $11.0 \pm 0.1$ \\
\hline Phosphate (mmol/l) & $1.8 \pm 0.1$ \\
\hline Protein $(\mathrm{g} / \mathrm{l})$ & $67.7 \pm 0.3$ \\
\hline Cholesterol (mmol/l) & $4.7 \pm 0.1$ \\
\hline C-reactive protein $(\mathrm{mg} / \mathrm{l})$ & $11.7 \pm 0.7$ \\
\hline
\end{tabular}

Mean values \pm SEM

a Self reported by patients 
Table 2 Characteristics-social and other data of dialyzed patients with chronic kidney disease

\begin{tabular}{ll}
\hline Marriage status & \\
Married & $434(62.3 \%)$ \\
Alone & $126(18.1 \%)$ \\
Widowed & $127(18.2 \%)$ \\
Living conditions & \\
With family & $585(83.9 \%)$ \\
Alone & $98(14.1 \%)$ \\
Education & \\
Elementary & $270(38.7 \%)$ \\
High school & $349(50.1 \%)$ \\
College & $66(9.5 \%)$ \\
Number of pills taken daily & $10.7 \pm 0.2$ \\
Number of days spent in hospital & $18.7 \pm 0.9$ \\
during the last year & \\
BDI score & $14.7 \pm 0.4$ \\
\hline
\end{tabular}

Mean values \pm SEM

$B D I$ beck depression inventory

haemodialyzed patients and correlates highly with diagnostic criteria for depression, quality of life, functional status, severity of illness and mortality over time [30, 31]. The BDI test uses 0-3 Likert scales, with total scores ranging from 0 to 63 . Higher scores correlate with more severe depression. BDI score $>16$ is characteristic for presence of moderate to severe depressive symptoms.

Social part of questionnaire considered marriage status, education and living conditions.

Medical history considered: primary illness as cause of CKD, additional illnesses, length of dialysis treatment, ownership type of dialysis centre (nonprofit or commercial), type of vascular access, number of days spent in hospitals during the last year and number of pills taken daily.

In each patient, the following laboratory results were obtained: blood haemoglobin concentration, serum protein, cholesterol and C-reactive protein concentrations. For these data collections, questionnaires were temporarily unblinded locally in dialysis centres.

Age, weight, height and gender of each patient were also obtained.

Participation in this study was voluntary and anonymous although good understanding of given questions was obligatory. Only complete questionnaires were investigated.
Statistical analysis was made with Statistica 5.0 PL program. Data were presented as means and standard error of means (SEM). Differences between groups were calculated with $T$ Student and $\chi^{2}$ tests. Correlation analysis was performed with Pearson's test and multiple regression test.

\section{Results}

Overall BDI score for studied population was $14.7 \pm 0.4$ points. Moderate to severe depressive symptoms of depression (BDI $>16$ ) were found in $268(38.6 \%)$ patients of studied population. Detailed comparison between groups with or without depression is shown in Table $3 a, b$.

If compared with patients without depressive symptoms, patients with depressive symptoms were older $(61.7 \pm 14.2$ vs. $57.5 \pm 14.4$ years, respectively; $p<0.001$ ), spent more days in hospitals during the last year (24.3 vs. 15.3 days, respectively; $p<0.001)$ and tended to have higher C-reactive protein plasma concentration $(14.3 \pm 1.3$ vs. $11.1 \pm 0.9 \mathrm{mg} / \mathrm{l}$, respectively; $p=0.067)$. Amongst patients with depressive symptoms there were more dialyzed ones with central catheter than in group without depressive symptoms (28 vs. $19 \%$, respectively; $p=0.004$ ) and more patients were treated by non-profit dialysis centres (70 vs. $59 \%$, respectively; $p=0,003)$. Patients dialyzed in non-profit dialysis centres spent more days in hospital during the last year than patients dialyzed in commercial ones (21.6 vs. 13.8 days, respectively; $p<0.001$ ).

In group with depressive symptoms there were more widowed patients than in group without depressive symptoms ( 24 vs. $13 \%$, respectively). Considering all investigated population, widowed patients had higher BDI score than married and lonely patients (17.7 vs. 14.3 points, respectively; $p<0.001$ and vs. 13.0 points; $p<0.001$, respectively). Married and lonely patients were not different with regard to BDI score (14.3 vs. 13.0 points, respectively; $p=0.162$ ).

There were also differences in education level-in the group with depressive symptoms there were 44/50/ $6 \%$ of patients after elementary, high schools and college comparing to $37 / 52 / 11 \%$ in the group without depressive symptoms, respectively $(p=0.027)$. Considering all investigated population, patients after college had significantly lower BDI score than 
Table 3 Characteristics and comparison between groups of haemodialyzed patients with ESRD with or without depressive symptoms

\begin{tabular}{|c|c|c|c|}
\hline & $\begin{array}{l}\text { Depressive } \\
\text { symptoms } \\
\text { group }\end{array}$ & $\begin{array}{l}\text { Non-depressive } \\
\text { symptoms group }\end{array}$ & $p$ \\
\hline \multicolumn{4}{|l|}{$a$} \\
\hline Number of patients & $268(38.6 \%)$ & $426(61.4 \%)$ & \\
\hline BDI score & 24.8 & 5.4 & \\
\hline Age (years) & $61.8 \pm 0.8$ & $57.5 \pm 0.7$ & 0.002 \\
\hline Weight (kg) & $71.7 \pm 0.9$ & $70.8 \pm 0.7$ & 0.438 \\
\hline \multicolumn{4}{|l|}{ Gender } \\
\hline Male & $141(52.6 \%)$ & $246(57.6 \%)$ & $0.185^{*}$ \\
\hline Female & $127(47.4 \%)$ & $180(42.4 \%)$ & \\
\hline $\begin{array}{l}\text { Haemodialysis time } \\
\text { per week }(\mathrm{h})\end{array}$ & $12.8 \pm 0.4$ & $12.6 \pm 0.2$ & 0.227 \\
\hline $\begin{array}{l}\text { Haemodialysis } \\
\text { time (years) }\end{array}$ & $3.5 \pm 0.3$ & $3.7 \pm 0.2$ & 0.616 \\
\hline \multicolumn{4}{|l|}{ Vascular access } \\
\hline Venous catheter & $77(27.6 \%)$ & $82(18.2 \%)$ & 0.004* \\
\hline Arterio-venous fistula & $191(72.4 \%)$ & $344(80.8 \%)$ & \\
\hline \multicolumn{4}{|l|}{ Dialysis centre } \\
\hline Non-profit & $186(70.2 \%)$ & $248(58.8 \%)$ & $0.003 *$ \\
\hline Commercial & $82(29.8 \%)$ & $178(41.2 \%)$ & \\
\hline \multicolumn{4}{|l|}{ Cause of $\mathrm{CKD}^{\mathrm{a}}$} \\
\hline Diabetes mellitus & $67(24.6 \%)$ & $81(19.1 \%)$ & $0.060 *$ \\
\hline Hypertension & $121(44.5 \%)$ & $163(38.4 \%)$ & $0.072 *$ \\
\hline Glomerulonephritis & $40(14.7 \%)$ & $82(19.3 \%)$ & $0.145^{*}$ \\
\hline Other & $39(14.3 \%)$ & $57(13.4 \%)$ & \\
\hline \multicolumn{4}{|l|}{ Other diseases ${ }^{\mathrm{a}}$} \\
\hline $\begin{array}{l}\text { Chronic pulmonary } \\
\text { obstructive disease }\end{array}$ & $11(4.0 \%)$ & $6(1.4 \%)$ & $0.025 *$ \\
\hline Coronary artery disease & $85(31.3 \%)$ & $81(19.1 \%)$ & 0.001* \\
\hline $\begin{array}{l}\text { History of myocardial } \\
\text { infarction }\end{array}$ & $42(15.4 \%)$ & $41(9.6 \%)$ & $0.017 *$ \\
\hline History of stroke & $28(10.3 \%)$ & $15(3.5 \%)$ & $<0.001 *$ \\
\hline Glaucoma & $22(8.1 \%)$ & $23(5.4 \%)$ & $0.143 *$ \\
\hline Hearing problems & $50(18.4 \%)$ & $59(13.9 \%)$ & $0.090 *$ \\
\hline \multicolumn{4}{|l|}{ Laboratory results } \\
\hline Haemoglobin (g/dl) & $10.9 \pm 0.1$ & $11.2 \pm 0.2$ & 0.166 \\
\hline Phosphate (mmol/l) & $1.8 \pm 0.0$ & $1.8 \pm 0.0$ & 0.845 \\
\hline Protein (g/l) & $66.8 \pm 0.6$ & $68.2 \pm 0.4$ & 0.058 \\
\hline Cholesterol $(\mathrm{mmol} / \mathrm{l})$ & $4.6 \pm 0.1$ & $4.7 \pm 0.1$ & 0.286 \\
\hline C-reactive protein $(\mathrm{mg} / \mathrm{l})$ & $14.3 \pm 1.3$ & $11.1 \pm 0.9$ & 0.067 \\
\hline \multicolumn{4}{|l|}{$b$} \\
\hline \multicolumn{4}{|l|}{ Marriage status } \\
\hline Married & $157(59.5 \%)$ & $277(65.5 \%)$ & 0.004 \\
\hline Alone & $42(15.9 \%)$ & $84(19.9 \%)$ & \\
\hline Widowed & $65(24.6 \%)$ & $62(14.7 \%)$ & \\
\hline \multicolumn{4}{|l|}{ Living conditions } \\
\hline With family & $219(83.3 \%)$ & $366(87.1 \%)$ & $0.160 *$ \\
\hline Alone & $44(16.7 \%)$ & $54(12.9 \%)$ & \\
\hline
\end{tabular}

Table 3 continued

\begin{tabular}{|c|c|c|c|}
\hline & $\begin{array}{l}\text { Depressive } \\
\text { symptoms } \\
\text { group }\end{array}$ & $\begin{array}{l}\text { Non-depressive } \\
\text { symptoms group }\end{array}$ & $p$ \\
\hline \multicolumn{4}{|l|}{ Education } \\
\hline Elementary & $117(44.0 \%)$ & $153(36.5 \%)$ & 0.027 \\
\hline High school & $132(49.6 \%)$ & $217(51.8 \%)$ & \\
\hline College & $17(6.4 \%)$ & $49(11.7 \%)$ & \\
\hline Number of pills taken daily & $10.9 \pm 0.3$ & $10.6 \pm 0.3$ & 0.490 \\
\hline $\begin{array}{l}\text { Number of days spent } \\
\text { in hospital during the } \\
\text { last year }\end{array}$ & $24.3 \pm 1.8$ & $15.3 \pm 1.0$ & $<0.001$ \\
\hline $\begin{array}{l}\text { Mean values } \pm \text { SEM } \\
* \chi^{2} \text { test } \\
{ }^{\text {a }} \text { Self reported by patients }\end{array}$ & & & \\
\hline $\begin{array}{l}\text { Bold values indicate statistic } \\
\text { patients after elemer } \\
(p=0.029) .\end{array}$ & 1 differences be & ween sub-groups & point \\
\hline
\end{tabular}

There were no significant differences between groups with regard to gender and family status (living alone or with family).

If compared with patients with arterio-venous fistula, the group of patients dialyzed with central venous catheter were characterized by significantly higher C-reactive protein serum concentration (15.9 vs. $11.0 \mathrm{mg} / \mathrm{l} ; p=0.013)$ and BDI score (16.7 vs. 14.0 points; $p=0.002$ ) (Table 4 ). This group was characterized also by more days spent in hospital during the last year (28.9 vs. $15.6 ; p<0,001)$ and shorter dialysis treatment time ( 2.9 vs. 3.8 years; $p=0.025$ ).

Significant positive correlations between BDI score and age $(r=0.152 ; p=0.002)$, days spent in hospitals during the last year $(r=0.210 ; p<0.001)$ and C-reactive protein level $(r=0.162 ; p=0.001)$ were found in entire studied population. Also multivariate regression analysis was performed with BDI score as dependent variable and independent variables: gender, age, time spent on dialysis treatment, type of vascular access, type of dialysis unit, marriage status, living conditions, educational level, number of pills taken daily, days spent in hospitals during the last year, blood concentrations of haemoglobin, plasma concentration of phosphate, cholesterol, protein and CRP. The multivariate regression analysis showed that BDI score depends on age ( $p=0.019$; beta $=0.117)$, days spent in hospitals during the last year $(p=0.004$; beta $=0.141)$ and C-reactive plasma concentration $(p=0.037$; beta $=0.099)$. 
Table 4 Comparison between patients dialyzed with the usage of arteriovenous fistula vs. central venous catheter

Analysis of whole investigated population $(n=694)$. Mean values \pm SEM

* $\chi^{2}$ test

Bold values indicate statistical differences between sub-groups

\begin{tabular}{lllr}
\hline & $\begin{array}{l}\text { Arterio-venous } \\
\text { fistula group }\end{array}$ & $\begin{array}{l}\text { Central venous } \\
\text { catheter group }\end{array}$ & $p$ \\
\hline Number of patients & $528(76.1 \%)$ & $166(23.9 \%)$ & \\
$\begin{array}{l}\text { Depression (BDI } \geq 16) \\
\text { BDI score }\end{array}$ & $189(35.8 \%)$ & $75(45.2 \%)$ & $\mathbf{0 . 0 2 9 *}$ \\
Age (years) & $14.0 \pm 0.4$ & $16.7 \pm 0.8$ & $\mathbf{0 . 0 0 2}$ \\
Haemodialysis time (years) & $57.9 \pm 0.6$ & $63.0 \pm 1.1$ & $<\mathbf{0 . 0 0 1}$ \\
Laboratory results & $3.8 \pm 0.2$ & $2.9 \pm 0.4$ & $\mathbf{0 . 0 2 5}$ \\
Haemoglobin (g/dl) & $11.1 \pm 0.2$ & $11.0 \pm 0.1$ & 0.682 \\
C-reactive protein (mg/l) & $11.0 \pm 0.7$ & $15.9 \pm 2.0$ & $\mathbf{0 . 0 1 3}$ \\
Number of days spent in hospital & $15.6 \pm 0.9$ & $28.9 \pm 2.4$ & $<\mathbf{0 . 0 0 1}$ \\
during the last year & & & \\
\hline
\end{tabular}

\section{Discussion}

Based on the results obtained in this study, which include the largest population of haemodialyzed patients diagnosed for the presence of depression in Poland, we can conclude that (a) depressive symptoms are frequent $(38 \%)$ and their presence mainly depends on time spent in hospitals and (b) presence of central catheter can be used as a simple marker to identify patients with higher risk for depression development.

Depressive symptoms rate in studied population is not different than reported before in many other studies [3, 13, 15, 30, 31]. We have anticipated that family-based culture as Polish may have some influence on depression presence in severely ill patients. It seems that cultural differences between dialyzed patients' populations (European, American, AfroAmerican, Taiwan, Japanese) do not affect depression development, which proves how profound impact on patients HRQOL, CKD stage 5.

Correlation between presence of depressive symptoms and time spent in hospitals during the last year may be bidirectional. It was already found that depression in haemodialyzed patients is associated with the higher rate of hospital admissions [32]. There are no data if treatment of depression can decrease hospitalization rate. And we do not know whether shortening time spent on treatment in hospital will decrease depression rate in haemodialyzed population. We assume that time spent in hospitals reflects overall patient's health status, seriousness of comorbidities and need for longer treatment. Causality in these circumstances is very hard to establish.

The difference in percentage of patients with depressive symptoms between profit and non-profit dialysis units requires wider comment. As we understand, there are two explanations of this finding. First is that the source of the patients of small non-profit dialysis units (which are in majority right now) is not large nephrological, emergency and cardiology public wards. Such sources are mainly outpatients' clinics. Second is that their deal with national health provider does not sufficiently cover expenses on seriously ill patients who stay longer in hospitals. These two reasons may create the situation, when in non-profit dialysis units there are more ill patients with lots of comorbidities and obviously higher rate of depression than in public centres. So, the difference in depressive symptoms rate between profit and non-profit dialysis units probably results from patients' allocation and reflects status of our healthcare system in this area.

Thus, it is established that during the first year after start of dialysis treatment, there is a higher rate of depression and suicides in this population [30]. This time is also characterized by wider usage of central catheters. Other subpopulation of haemodialyzed patients are those with problems with vascular access, with history of many catheters used and with many vascular changes. Our study did not make a difference between these two subgroups. All catheter bearers were identified as a group with significantly higher BDI score, higher C-reactive protein plasma concentration and more days spent in hospital during the last year. Such a correlation was not observed in 109 patients investigated by Leinau et al. [33]. Although, there is connection between presence of a central catheter and higher possibility of infection and inflammation, we conclude that higher plasma C-reactive protein level in patients with central catheter reflects overall worse inflammatory status of these 
patients which implicate more intensive treatment in hospitals.

First episode of depression in general population mainly occurs below 30 years of age [34] and its prevalence declines with the age. In our population, depression was positively correlated with age, and time of dialysis treatment was not different in groups with or without depressive symptoms. This is contrary to previous findings in which depression is mainly bound to the first 12 months of dialysis treatment with the higher rate of suicides, especially in younger patients. This difference could be explained by "advanced" average age of whole investigated population and their marital status, which can be characterized as "middleaged", in majority married (62\%) and living with family $(84 \%)$. That obviously delivers enough social support. On the other hand, it is understandable that the longer patients are dialyzed, the higher rate of complications and comorbidities occurs, with higher possibility of depression development.

One of the more surprising findings was the same rate of depression in haemodialyzed man and woman. It is known that depression is much more frequent (2 times) in woman than in man all over the world in different cultures [35]. This is related mainly to higher stress rate and lower amount of inner resources in woman. It seems that overall burden connected to chronic kidney disease and dialysis treatment levels the stress rate in men and woman, and gender differences stop to play an important role in depression development. This could be rather due to rise of stress level in man than decrease stress in woman in dialysis population. This is the only speculation, because this area was not investigated.

Recently, many authors have tried to find a connection between depression and aggravated inflammatory status of patients with ESRD [36]. It was proven that proinflammatory cytokines play an important role in the pathogenesis of depression in general population [37, 38]. The same cytokines are elevated in ESRD patients $[39,40]$ and may predict mortality in this group [41]. Also C-reactive protein (CRP) concentration was used to predict outcome in haemodialysis patients [42]. Amongst others, interleukin-6 (IL-6) became most often used marker to link depression and inflammation in patients with CKD, ESRD and after kidney transplantation [40, 43, 44]. Elevated IL-6 level may increase risk of depression development in patients with ESRD [45, 46].
Causality of depression and inflammation is unclear, probably bilateral. It was found that depression is linked to worse nutritional status of patients with ESRD [25] that is the part of malnutrition-inflammation-atherosclerosis (MIA) syndrome. Salawa and Omima showed in 60 haemodialysis patients the link between depressive symptoms, poor quality of life and malnutrition-inflammation complex assessed with MIA [42]. Additionally, depression is associated with higher cardiovascular risk in patients with ESRD [2628], which also could be mediated through depressionaggravated atherosclerosis.

Our study has several limitations. We did not include all patients dialyzed in our region (30\% of all of them were included). Those who could not or did not want to participate were not investigated. This certainly underestimated the presence of depression as non-compliance is a depression marker, and as inability to fulfil questionnaire reflects much worse general state of patient. We did not collected data about work activities and being on waiting list for transplantation. We may assume that working patients and those who await transplantation have better (lower) BDI score. We chose $\mathrm{C}$-reactive protein as a marker for inflammation because of its low cost in regard to large studied population, although as presented recently in many papers, IL-6 seems to be a better marker. The data concerning cause of $\mathrm{CKD}$ and comorbidities were obtained from the patients - so credibility of this data may be questioned. We did not investigated presence of pain, fatigue and quality of sleep in studied population. They were proven in other studies to affect depression rate in haemodialyzed population.

In summary, this study once again proved high prevalence of depressive symptoms in haemodialyzed patients. We confirmed a link between depression and inflammatory status in large group of patients, and we identified a subpopulation of catheter bearers as a group with high risk for depression development. The efforts should be made to shorten inpatients' treatment time to decrease occurrence of severe depression. One of the ways to achieve this is early diagnosis of CKD and starting dialysis treatment with already ready-topuncture arterio-venous fistula. We suggest considering usage of MIAD syndrome instead of MIA abbreviation but this idea requires further studies.

Conclusions: 1. Depressive symptoms are frequently found $(38.6 \%)$ in haemodialyzed patients in Upper Silesia part of Poland. 2. Catheter placement 
and inflammation seem to play an important role in the pathogenesis of depression in haemodialysis patients.

Open Access This article is distributed under the terms of the Creative Commons Attribution License which permits any use, distribution, and reproduction in any medium, provided the original author(s) and the source are credited.

\section{References}

1. Ricardo AC, Fischer MJ, Peck A, Turyk M, Lash JP (2010) Depressive symptoms and chronic kidney disease: results from the National Health and Nutrition Examination Survey (NHANES) 2005-2006. Int Urol Nephrol 42:1063-1068

2. Blazer DG, Kessler RC, McGonagle KA, Swartz MS (1994) The prevalence and distribution of major depression in a national community sample: the National Comorbidity Survey. Am J Psychiatry 151:979-986

3. Murtagh FE, Addington-Hall J, Higginson IJ (2007) The prevalence of symptoms in end-stage renal disease: a systematic review. Adv Chronic Kidney Dis 14:82-99

4. Craven JL, Rodin GM, Littlefield C (1988) The Beck Depression Inventory as a screening device for major depression in renal dialysis patients. Int J Psychiatry Med 18:365-374

5. Lowry MR, Atcherson E (1980) A short-term follow-up of patients with depressive disorder on entry into home hemodialysis training. J Affect Disord 2:219-227

6. Kimmel PL, Thamer M, Richard CM, Ray NF (1998) Psychiatric illness in patients with end-stage renal disease. Am J Med 105:214-221

7. Smith MD, Hong BA, Robson AM (1985) Diagnosis of depression in patients with end-stage renal disease: comparative analysis. Am J Med 79:160-166

8. Cukor D, Peterson RA, Cohen SD, Kimmel PL (2006) Depression in end-stage renal disease hemodialysis patients. Nat Clin Pract Nephrol 2:678-687

9. Hedayati SS, Bosworth HB, Kuchibhatla M, Kimmel PL, Szczech LA (2006) The predictive value of self-report scales compared with physician diagnosis of depression in hemodialysis patients. Kidney Int 69:1662-1668

10. Kimmel PL (2001) Psychosocial factors in dialysis patients. Kidney Int 59:1599-1613

11. Grant D, Almond MK, Newnham A, Roberts P, Hutchings A (2008) The Beck Depression Inventory requires modification in scoring before use in a haemodialysis population in the UK. Nephron Clin Pract 110:33-38

12. DiMatteo MR, Lepper HS, Croghan TW (2000) Depression is a risk factor for noncompliance with medical treatment: meta-analysis of the effects of anxiety and depression on patient adherence. Arch Intern Med 160:2101-2107

13. Khalil AA, Frazier SK (2010) Depressive symptoms and dietary nonadherence in patients with end-stage renal disease receiving hemodialysis: a review of quantitative evidence. Issues Ment Health Nurs 31:324-330

14. Cukor D, Rosenthal DS, Jindal RM, Brown CD, Kimmel PL (2009) Depression is an important contributor to low medication adherence in hemodialyzed patients and transplant recipients. Kidney Int 75:1223-1229

15. Allison SJ (2010) Chronic kidney disease: depression is associated with poor outcomes in early CKD. Nat Rev Nephrol 6:446

16. Hedayati SS, Minhajuddin AT, Afshar M, Toto RD, Trivedi MH, Rush AJ (2010) Association between major depressive episodes in patients with chronic kidney disease and initiation of dialysis, hospitalization, or death. JAMA 19:19461953

17. Young BA, Von Korff M, Heckbert SR, Ludman EJ, Rutter C, Lin EH, Ciechanowski PS, Oliver M, Williams L, Himmelfarb J, Katon WJ (2010) Association of major depression and mortality in Stage 5 diabetic chronic kidney disease. Gen Hosp Psychiatry 32:119-124

18. Kimmel PL, Peterson RA, Weihs KL, Simmens SJ, Alleyne S, Cruz I, Veis JH (2000) Multiple measurements of depression predict mortality in a longitudinal study of chronic hemodialysis outpatients. Kidney Int 57:2093-2098

19. Boulware LE, Liu Y, Fink NE, Coresh J, Ford DE, Klag MJ, Powe NR (2006) Temporal relation among depression symptoms, cardiovascular disease events, and mortality in end-stage renal disease: contribution of reverse causality. Clin J Am Soc Nephrol 1:496-504

20. Kurella M, Kimmel PL, Young BS, Chertow GM (2005) Suicide in the United States end-stage renal disease program. J Am Soc Nephrol 16:774-781

21. Odden MC, Whooley MA, Shlipak MG (2006) Depression, stress, and quality of life in persons with chronic kidney disease: the heart and soul study. Nephron Clin Pract 103:1-7

22. Cohen SD, Patel SS, Khetpal P, Peterson RA, Kimmel PL (2007) Pain, sleep disturbance, and quality of life in patients with chronic kidney disease. Clin J Am Soc Nephrol 2:919925

23. Park HC, Yoon HB, Son MJ, Jung ES, Joo KW, Chin HJ, Oh KH, Lim CS, Kim YS, Ahn C, Han JS, Kim S, Hahm BJ, Oh YK (2010) Depression and health-related quality of life in maintenance hemodialysis patients. Clin Nephrol 73: 374-380

24. Araujo SM, de Bruin VM, Daher ED, Almeida GH, Medeiros CA, de Bruin PF (2012) Risk factors for depressive symptoms in a large population on chronic hemodialysis. Int Urol Nephrol 44:1229-1235

25. Ibrahim S, El Salamony O (2008) Depression, quality of life and malnutrition-inflammation scores in hemodialysis patients. Am J Nephrol 28:784-791

26. Stenvinkel P, Lindholm B, Heimburger M (2000) Elevated serum levels of soluble adhesion molecules predict death in pre-dialysis patients: association with malnutrition, inflammation, and cardiovascular disease. Nephrol Dial Transplant 15:1624-1630

27. Qureshi AR, Alvestrand A, Divino-Filho JC (2002) Inflammation, malnutrition, and cardiac disease as predictors of mortality in hemodialysis patients. J Am Soc Nephrol 13:28-36

28. Ko GJ, Kim MG, Yu YM, Jo SK, Cho WY, Kim HK (2010) Association between depression symptoms with inflammation and cardiovascular risk factors in patients undergoing peritoneal dialysis. Nephron Clin Pract 116:c29-c35 
29. Beck AT, Steer RA, Brown GK (1996) BDI-II manual, 2nd edn. Harcourt Brace and Company, San Antonio

30. Kimmel PL, Weihs K, Peterson RA (1993) Survival in hemodialysis patients: the role of depression. J Am Soc Nephrol 4:12-27

31. Sacks CR, Peterson RA, Kimmel PL (1990) Perception of illness and depression in chronic renal disease. Am J Kidney Dis 15:31-39

32. Abbas Tavallaii S, Ebrahimnia M, Shamspour N, Assari S (2009) Effect of depression on health care utilization in patients with end-stage renal disease treated with hemodialysis. Eur J Intern Med 20:411-414

33. Leinau L, Murphy TE, Bradley E, Fried T (2009) Relationship between conditions addressed by hemodialysis guidelines and non-ESRD-specific conditions affecting quality of life. Clin J Am Soc Nephrol 4:572-578

34. Burke KC, Burke JD, Reiger DA, Rae DS (1990) Age at onset of selected mental disorders in five community populations. Arch Gen Psychiatry 47:511-518

35. Weissman M, Olfson M (1995) Depression in women: implications for health care research. Science 269:799-801

36. Li ZJ, An X, Mao HP, Wei X, Chen JH, Yang X, Zhou SF, Li ZB, Yu XQ (2011) Association between depression and malnutrition-inflammation complex syndrome in patients with continuous ambulatory peritoneal dialysis. Int Urol Nephrol 43:875-882

37. Segerstrom SC, Miller GE (2004) Psychological stress and the human immune system: a meta-analytic study of 30 years of inquiry. Psychol Bull 130:601-630

38. Miller GE, Cohen S, Ritchey AK (2002) Chronic psychological stress and the regulation of pro-inflammatory cytokines: a glucocorticoid-resistance model. Health Psychol 21:531-541
39. Kimmel PL, Phillips TM, Simmens SJ, Peterson RA, Weihs KL, Alleyne S, Cruz I, Yanovski JA, Veis JH (1998) Immunologic function and survival in hemodialysis patients. Kidney Int 54:236-244

40. Stenvinkel P, Barany P, Heimburger O (2002) Mortality, malnutrition, and atherosclerosis in ESRD: what is the role of interleukin-6? Kidney Int Suppl 80:103-108

41. Stenvinkel P, Alvestrand A (2002) Inflammation in endstage renal disease: sources, consequences, and therapy. Sem Dialysis 15:329-337

42. Owen WF, Lowrie EG (1998) C-reactive protein as an outcome predictor for maintenance hemodialysis patients. Kid Int 54:627-636

43. Bossola M, Ciciarelli C, Di Stasio E, Conte GL, Vulpio C, Luciani G, Tazza L (2010) Correlates of symptoms of depression and anxiety in chronic hemodialysis patients. Gen Hosp Psychiatry 32:125-131

44. Czira ME, Lindner AV, Szeifert L, Molnar MZ, Fornadi K, Kelemen A, Laszlo G, Mucsi I, Keszei AP, Kennedy SH, Novak M (2011) Association between the malnutritioninflammation score and depressive symptoms in kidney transplanted patients. Gen Hosp Psychiatry 33:157-165

45. Sonikian M, Metaxaki P, Papavasileiou D, Boufidou F, Nikolaou C, Vlassopoulos D, Vlahakos DV (2010) Effects of interleukin- 6 on depression risk in dialysis patients. Am J Nephrol 31:303-308

46. Hung KC, Wu CC, Chen HS, Ma WY, Tseng CF, Yang LK, Hsieh HL, Lu KC (2011) Serum IL-6, albumin and co-morbidities are closely correlated with symptoms of depression in patients on maintenance haemodialysis. Nephrol Dial Transplant 26:658-664 